\title{
Dampak Penerapan Kebijakan Pemerintah terhadap Eksternalitas Sampah Plastik Di Kota Jayapura
}

\section{The Impact of Government Policies Implementation on Plastic Waste Externalities in Jayapura City}

\author{
Christina Irwati Tanan $^{1)}$, Jimmi Ari Duri ${ }^{2)}$, Dwi Utari Tamanbali ${ }^{3)}$ \\ ${ }^{1,2,3)}$ Fakultas Ekonomi, Universitas Ottow Geissler, Papua \\ e-mail korespondensi: christinatanan06@gmail.com
}

\begin{tabular}{|l|}
\hline Info Artikel \\
\hline Riwayat Artikel : \\
Diterima: 07 November 2020 \\
Disetujui: 21 Maret 2021 \\
Dipublikasikan: Juli 2021 \\
\hline Nomor DOI \\
10.33059/jseb.v12i2.2848 \\
Cara Mensitasi : \\
Tanan, C. I., Duri, J. A., \& \\
Tamanbali, D. U. (2021). \\
Dampak penerapan kebijakan \\
pemerintah terhadap \\
eksternalitas sampah plastik di \\
Kota Jayapura. Jurnal \\
Samudra Ekonomi dan Bisnis, \\
12(2), 228-241. doi: \\
10.33059/jseb.v12i2.2848.
\end{tabular}

\begin{abstract}
Abstrak
Penelitian ini bertujuan untuk mengetahui kebijakan pemerintah dan dampaknya terhadap pengelolaan sampah plastik di Kota Jayapura selama tahun 2017-2020. Penelitian ini dilakukan di Kantor Lingkungan dan Kebersihan. Dengan menggunakan metode analisis data kualitatif, penelitian ini melibatkan 230 responden masyarakat. Hasil yang diperoleh menunjukkan bahwa mayoritas masyarakat menilai kebijakan pemerintah Kota Jayapura tentang pengelolaan sampah plastik telah mampu menekan jumlah sampah plastik. Namun demikian, masih banyak dari anggota masyarakat yang menilai Pemprov belum sepenuhnya mampu menekan jumlah sampah plastik, serta percaya kebijakan tersebut tidak mampu mengurangi sampah plastik di kota. Berdasarkan hasil yang diperoleh, diharapkan kebijakan ini juga dapat diterapkan di pasar tradisional sehingga bisa semakin mengurangi penggunaan kantong plastik dan mengurangi sampah plastik di Kota Jayapura.
\end{abstract}

Kata Kunci: Sampah Plastik, Kebijakan Pemerintah, Kota Jayapura.

\begin{tabular}{|c|c|}
\hline Article Info & Abstract \\
\hline $\begin{array}{l}\text { Article History: } \\
\text { Received: } 07 \text { November } 2020 \\
\text { Accepted: } 21 \text { March } 2021 \\
\text { Published: July } 2021\end{array}$ & $\begin{array}{l}\text { This study aims to determine government policies and their impact on plastic } \\
\text { waste management in Jayapura City in } 2017-2020 \text {. The study was conducted at } \\
\text { the Environmental and Cleanliness Office. Using qualitative data analysis } \\
\text { methods, the study involved } 230 \text { community respondents. The results indicate }\end{array}$ \\
\hline $\begin{array}{l}\text { DOI Number: } \\
\text { 10.33059/jseb.v12i2.2848 } \\
\text { How to cite : } \\
\text { Tanan, C. I., Duri, J. A., \& } \\
\text { Tamanbali, D. U. (2021). } \\
\text { Dampak penerapan kebijakan } \\
\text { pemerintah terhadap } \\
\text { eksternalitas sampah plastik di } \\
\text { Kota Jayapura. Jurnal } \\
\text { Samudra Ekonomi dan Bisnis, } \\
\text { 12(2), 228-241. doi: } \\
\text { 10.33059/jseb.v12i2.2848. }\end{array}$ & $\begin{array}{l}\text { that the majority of the public consider the Jayapura City government's policy } \\
\text { on plastic waste management to have been able to reduce the amount of plastic } \\
\text { waste. However, there are still many community members who think that the } \\
\text { provincial government has not been able to fully reduce the amount of plastic } \\
\text { waste, and believe that the policy is not able to reduce plastic waste in the city. } \\
\text { Based on the results obtained, it is hoped that this policy can also be applied in } \\
\text { traditional markets so that it can further reduce the use of plastic bags and } \\
\text { reduce plastic waste in Jayapura City. } \\
\text { Keywords: Plastic Waste, Government Policies, Jayapura City. }\end{array}$ \\
\hline
\end{tabular}




\section{PENDAHULUAN}

Berdasarkan data dari Dinas Kebersihan Kota Jayapura bahwa pencemaran lingkungan akibat sampah plastik di Kota Jayapura, diperkirakan 1 atau 2 ton sampah dalam satu hari diangkut pada pembuangan akhir (TPA) (Ramah, 2017). Adanya kebijakan mengenai pembatasan timbunan sampah plastik sekali pakai dapat mengurangi pemakai plastik (Putri, 2019).

Andrawina et al. (2019) memperoleh hasil riset bahwa 85,42 persen diantaranya bersedia mendukung kebijakan pemerintah dalam mengurangi penggunaan plastik, dan 40 persen diantaranya berpartisipasi dalam kebijakan plastik terutang. Sementara itu, Utcha \& Chavalparit (2019) meneliti bahwa Thailand telah menetapkan Strategi 3R Nasional serta Rencana Induk Nasional Pengelolaan Sampah (2016-2021), selain juga meluncurkan "Rencana Pengelolaan Sampah Plastik 2017-2021", yang terdiri dari beberapa pendekatan.

Untuk itu dibutuhkan peran pemerintah dalam mengatasi eksternalitas negatif dari adanya penggunaan plastik di masyarakat sebagai akibat dari kegiatan ekonomi produsen dan konsumen yang mengakibatkan munculnya dampak negatif. Hal ini karena eksternalitas sampah plastik terjadi karena besarnya penggunaan plastik di masyarakat padahal ketergantungan pada plastik sekali pakai berdampak buruk bagi lingkungan dan manusia, karena mencemari lingkungan juga menjadi ancaman bagi kesehatan kita. Dengan adanya bahaya yang timbul dari penggunaan plastik maka pemerintah berupaya melalui kebijakan dan programnya untuk mengurangi penggunaan plastik sehingga menurunkan sampah plastik.

Berbagai upaya dilakukan pemerintah untuk mengatasi masalah eksternalitas sampah plastik baik melalui kebijakannya, program bank sampah yang dilakukan di masyarakat bahkan pelatihan daur ulang sampah plastik yang berhubungan dengan pengelolaan sampah plastik. Upaya yang dilakukan Pemerintah Kota Jayapura dalam mengatasi masalah sampah plastik, seperti program pemerintah dalam menurunkan sampah plastik, melakukan pengolahan sampah berupa kegiatan daur ulang serta larangan menggunakan kantong belanja plastik, strategi tanpa sampah, dan recycling strategy yang ditujukan kepada perilaku manusia untuk mengurangi limbah (Willis et al., 2018).

Salah satu regulasi Pemerintah Kota Jayapura untuk menurunkan sampah plastik dengan dikeluarkannya Instruksi Walikota No. 1 tahun 2019 mengenai penerapan penggunaan kantong belanja alternatif pengganti kantong plastik di Kota Jayapura. Penerapan peraturan ini efektif dilaksanakan pada tanggal 1 Februari 2019 (Tanan \& Duri, 2021). Sampai dengan saat ini upaya ini belum sepenuhnya mengurangi penggunaan plastik di masyarakat. Muslihun et al. (2020) menemukan bahwa kebijakan kantong plastik berbayar mendapat dukungan dari pemerintah daerah, pelaku usaha maupun konsumen. Meskipun konsumen mengetahui dan telah mendukung kebijakan ini, namun dalam kenyataannya tidak banyak mengubah pola perilaku dari konsumen.

Perencanaan dan kebijakan pemerintah atas masalah sampah plastik karenanya perlu dievaluasi untuk menganalisis dampaknya di masyarakat. Penelitian ini berfokus pada upaya memahami bagaimana kebijakan pemerintah serta menganalisis dampak akibat penerapan kebijakan pemerintah tersebut terhadap eksternalitas sampah plastik di Kota Jayapura. Persoalan ini dinilai penting karena menjadi studi kasus mengenai bagaimana kebijakan pemerintah daerah dalam mengatasi masalah dan pengelolaan sampah plastik, khususnya wilayah di Kota Jayapura. 


\section{Eksternalitas (Dampak sampingan)}

Eksternalitas adalah kegiatan yang bisa berpengaruh pada tingkat kesejahteraan orang atau pihak lain. Untuk itu dapat diukur atau dinilai dengan uang, akan tetapi tidak dimasukkan ke dalam harga produk yang dihasilkan. Eksternalitas dapat timbul karena adanya kegiatan seseorang yang berdampak pada orang lain (sekumpulan atau sekelompok orang lain), tetapi tidak memperoleh kompensasi ataupun balas jasa, sehingga hal ini dapat mengakibatkan atau berdampak pada inefisiensi pada alokasi faktor produk (Mangkoesoebroto, 2016).

Menurut Prasetyia (2012), eksternalitas ada karena variabel dependen berupa adanya pelaku ekonomi tertentu mengganggu fungsi utilitas (fungsi kegunaan) terhadap pelaku ekonomi lain. Kegiatan produksi suatu barang efeknya dapat memperoleh manfaat atau biaya dimana belum diperhitungkan proses produksi dari barang yang dihasilkan, karena adanya mekanisme pasar tidak dimasukan dalam semua biaya atau manfaat sosial.

Salah satu contoh eksternalitas negatif adalah pembuangan kemasan makanan dan minuman (seperti: plastik, botol-botol plastik) secara begitu saja sehingga berdampak pada lingkungan sekitarnya. Kemasan yang sudah habis masa pakainya saat ini merupakan salah satu masalah lingkungan utama karena waktu penggunaan yang singkat (Ciuffi et al., 2020).

\section{Masalah Pengelolaan Sampah Plastik}

Menurut Program Lingkungan PBB (UNEP), antara 22 hingga 43 persen plastik yang dipergunakan dibuang pada tempat pembuangan sampah yang ada. Demikian juga, diperkirakan 10 hingga 20 juta ton sampah plastik mengakibatkan pencemaran di lautan setiap tahunnya (Muryono, 2018). Walaupun belum didapatkan adanya data yang pasti atau akurat tentang seberapa besar jumlah pencemaran sampah plastik di
Indonesia, KLHK menyatakan sampah plastik dari 100 toko/gerai anggota ASPRINDO selama kurun waktu satu tahun menghasilkan 10,95 juta lembar sampah kantong plastik. Menurut pihak Indonesia Solid Waste Association (InSWA), produksi sampah plastik yang ada di Indonesia diperkirakan sebanyak 5,4 juta ton per tahun (Yuliyah, 2018).

Menurut Undang-undang Nomor 23 Tahun 1997 tentang Pengelolaan Lingkungan Hidup, lingkungan sebagai kesatuan dengan segala sesuatu ruang, daya, keadaan, dan makhluk hidup, termasuk manusia, dan perilaku, yang mempengaruhi kelangsungan mata pencaharian dan kesejahteraan manusia dan makhluk hidup lainnya (Siahaan, 2004). Pengelolaan sampah di Indonesia sesungguhnya sudah diatur dalam Undang-Undang Nomor 18 Tahun 2008 dan PP Nomor 81 Tahun 2012 tentang pengolahan sampah di Indonesia (Astuti, 2018).

Bermacam cara telah dilakukan dalam menyelesaikan masalah pencemaran sebagai akibat dari sampah plastik. Salah satu cara adalah daur ulang, yaitu proses dengan membuat bahan bekas pakai yang dapat menghasilkan bahan yang baru. Kegiatan mendaur ulang dianggap dapat mengurangi atau menurunkan jumlah sampah plastik yang tidak dimanfaatkan. Cara lain yaitu penggunaan alat incinerator pada pusat-pusat incinerator yang berlokasi di luar kota, dimana sampah plastik dapat dimusnahkan dengan cara dibakar. Cara ini dapat mengatasi pengurangan bahan plastik dalam volume besar, serta dapat menekan tingkat ketergantungan atas plastik yang berlebihan.

Pemerintah di sejumlah negara maju dan berkembang telah membuat pelarangan ataupun pembatasan produk plastik dengan melarang pembuatan atau produksi dan penjualan kantong plastik. Pada saat kegiatan berbelanja, masyarakat disarankan memakai 
tas kertas atau tas berbahan kain lainnya, seperti rami, katun, atau bahan lainnya yang ramah lingkungan.

Palugaswewa (2018) meneliti kebijakan pemerintah Sri Lanka yang telah menetapkan berbagai alternatif sebagai pilihan untuk memajukan sistem pengelolaan limbah atau sampah di negaranya. Beberapa upaya yang dilakukan adalah mengembangkan kebijakan, strategi, juga pedoman penetapan peraturan, dan juga menyediakan fasilitas instrastruktur untuk dapat dipergunakan dalam pengelolaan limbah atau sampah. Olusunmade (2019) dalam studinya menemukan bahwa meskipun hampir 50 persen dari populasi yang diteliti mengaku sadar akan bahaya limbah plastik, tapi masih terdapat ketidakpedulian dalam cara penanganan limbah ini, seperti yang dapat diamati dari pembuangan limbah secara sembarangan, menciptakan sampah di sekitar lingkungan.

Di wilayah China, diperkirakan 111 juta metrik ton sampah plastik akan dipindahkan dengan kebijakan baru oleh pemerintah negara tersebut pada tahun 2030 (Brooks et al., 2018). Dari kasus negara China tersebut dipahami bahwa diperlukan ide dan tindakan global untuk mengurangi jumlah bahan yang tidak dapat didaur ulang, yaitu dengan mendesain ulang. Khan et al. (2019) dalam studinya menemukan bahwa level konsumsi plastik telah meningkat secara global, yang menghasilkan sampah dalam jumlah besar dan menimbulkan ancaman bagi lingkungan. Kebijakan daur ulang sampah plastik karenanya dinilai bisa membantu mengurangi sampah dan ancaman lingkungannya.

\section{Kebijakan Pemerintah terhadap Masalah Sampah Plastik}

Masalah sampah sudah menjadi masalah serius yang ditangani Pemerintah Indonesia (Septiadi, 2018). Peraturan Presiden (Perpres) Nomor 97 Tahun 2017 tentang Kebijakan dan
Strategi Nasional Pengelolaan Sampah Rumah Tangga dan Sampah Sejenis Sampah Rumah Tangga menyatakan pemerintah menetapkan kebijakan dan strategi pengelolaan sampah nasional (Jakstranas). Peraturan tersebut juga termasuk sampah plastik di laut dimana regulasi yang ada bersifat lebih ketat dan spesifik. Peraturan ini diperlukan sebagai pedoman strategi jangka panjang dalam penanganan pencemaran plastik laut di Indonesia, dan analisis yang tepat mengenai dampak regulasi tersebut terhadap pemangku kepentingan dan pihak yang terkena dampak juga akan diperlukan (Prisandani \& Amanda, 2019).

Pembudayaan hidup ramah lingkungan melalui kebijakan kantong plastik berbayar oleh Kementerian Lingkungan Hidup dan Kehutanan dapat menurunkan masalah yang disebabkan oleh sampah plastik (Novianti \& Kartika, 2017). Pemerintah Kota Jayapura telah menerapkan larangan penggunaan kantong plastik di pasar modern dan pusat perbelanjaan serta resmi diterapkan dalam masyarakat di Kota Jayapura mulai tanggal 1 Februari 2019. Larangan penggunaan kantong plastik ini berdasarkan Instruksi Walikota Jayapura Nomor 1/2019, tentang penerapan penggunaan kantong belanja alternatif pengganti kantong plastik di Kota Jayapura. Sebenarnya pada tahun 2016-2017 penerapan larangan penggunaan kantong plastik telah mulai diberlakukan dengan menerapkan penggunaan kantong plastik berbayar maupun kantong plastik yang ramah lingkungan di tempat pusat perbelanjaan di Kota Jayapura, yang diharapkan menjadi satu solusi dalam menurunkan sampah plastik di kota itu.

Pembatasan sampah sejak awal membutuhkan pemberdayaan masyarakat dan juga kebijakan strategis yang dilakukan oleh pihak pemerintah melalui pembinaan kepada pihak masyarakat, juga dengan penerapan kemajuan teknologi terkini (Yustikarini et al., 2017). 
Program Bank Sampah merupakan penerapan upaya kebijakan dengan mendaur ulang sampah menyediakan fasilitas dan sosialisasi pengolahan sampah. Perpaduan kebijakan fiskal insentif dan disinsentif dapat menekan jumlah sampah plastik menjadi berkurang (Purwoko \& Wibowo, 2018; Wanda, 2019). Kebijakan pemerintah dalam program pengelolaan sampah melalui bentuk keterlibatan keaktifan masyarakat dengan mengumpulkan dan mengangkut sampah, jejaring pengolahan sampah mandiri dan mobil hijau (Mulasari et al., 2014). Studi milik Fangga \& Mulasari (2016) menemukan situasi adanya kelompok masyarakat yang secara aktif mengelola sampah rumah tangga dan selanjutnya mendapatkan insentif dari Pemerintah Bantul. Temuan riset Maolani \& Ishak (2018) memperoleh fakta program pemberdayaan masyarakat yang dilakukan Pemerintah Kabupaten Dili melalui sejumlah program seperti penyuluhan lingkungan terkait pengelolaan sampah, menyediakan bak sampah di setiap desa, proses pengangkutan sampah dari tempat pembuangan sementara sampai kepada tempat pembuangan akhir.

Berdasarkan hasil penelitiannya, Wang et al. (2020) merekomendasikan beberapa hal. Pertama, peningkatan insentif atau denda dapat meningkatkan kemungkinan bahwa pengumpul maupun pendaur ulang akan berpartisipasi dalam proses daur ulang. Kedua, bentuk insentif dukungan kebijakan bisa mendorong pengumpul dan pendaur ulang untuk berpartisipasi dalam daur ulang sampah plastik lebih awal daripada insentif subsidi. Terakhir, pendaur ulang berperilaku lebih sensitif daripada kolektor terhadap hukuman yang diberlakukan pemerintah.

Pengelolaan sampah karenanya adalah bentuk tanggungjawab bersama yang perlu dikelola dengan baik. Pengelolaan sampah plastik yang bertujuan mengurangi volume sampah plastik itu membutuhkan keterlibatan bersama antara pemerintah dan masyarakat secara aktif. Upaya-upaya yang bisa dijalankan seperti melalui program bak sampah, penyediaan fasilitas, atau kombinasi kebijakan fiskal insentif dan disinsentif. Sejumlah upaya ini perlu diupayakan demi memberikan manfaat berupa lingkungan menjadi bersih, asri dan nyaman, dan juga mendatangkan manfaat ekonomi.

\section{Dampak Penerapan Kebijakan Pemerintah terhadap Pengelolaan Sampah Plastik}

Program Bank Sampah memberikan dampak positif baik kepada masyarakat maupun lingkungan. Hal ini dinilai sangat membantu pemerintah berkenaan dengan upaya menurunkan volume sampah (Saputri, 2015). Namun demikian, toko ritel modern tidak merasakan dampak perubahan yang nyata dalam aspek ekonomi dengan adanya kebijakan kantong plastik berbayar yang diterapkan (Saraswaty, 2018). Bentuk dampak negatif yang muncul adalah karena TPA mendapatkan beban sampah yang paling besar sebagai lokasi ujung akhir pengelolaan sampah. Penanggulangan dampak dari pencemaran seperti biaya pengolahan limbah, biaya pengumpulan dan pembuangan sampah (eksternalitas negatif) dilakukan melalui pengenaan cukai pada produk plastik.

Untuk mengatasi permasalahan terkait pengelolaan sampah plastik di daerah diperlukan peraturan pemerintah, fasilitas pendukung, serta keterlibatan aktif semua lapisan masyarakat untuk bersama-sama menurunkan sampah plastik yang ada di lingkungan dan sampai di TPA. Widiantara (2020) menemukan penetapan Peraturan Gubernur Bali tentang pembatasan timbunan sampah plastik sekali pakai telah ditanggapi secara positif oleh banyak pihak seperti penggiat dan komunitas lingkungan, maupun berbagai komponen masyarakat lainnya. 
Regulasi untuk pengelolaan sampah plastik laut, diantaranya Peraturan Presiden Nomor 83 Tahun 2018 tentang Pengelolaan Sampah Laut, dan masyarakat Indonesia telah berperan aktif dalam mengurangi sampah plastik (Prisandani \& Amanda, 2019). Bai et al. (2018) menyarankan untuk memperkuat tata kelola dan pengendalian sampah plastik pada kegiatan perikanan pesisir di wilayah ang bersangkutan guna upaya mengurangi jumlah sampah plastik di laut. Lebih jauh, tantangan yang muncul dalam pengelolaan limbah selama dan setelah pandemi yaitu perlunya sistem pengelolaan sampah yang responsif secara dinamis, serta disarankan untuk mengurangi potensi dampak pandemi pada sistem dalam pengelolaan limbah (Klemeš et al., 2020).

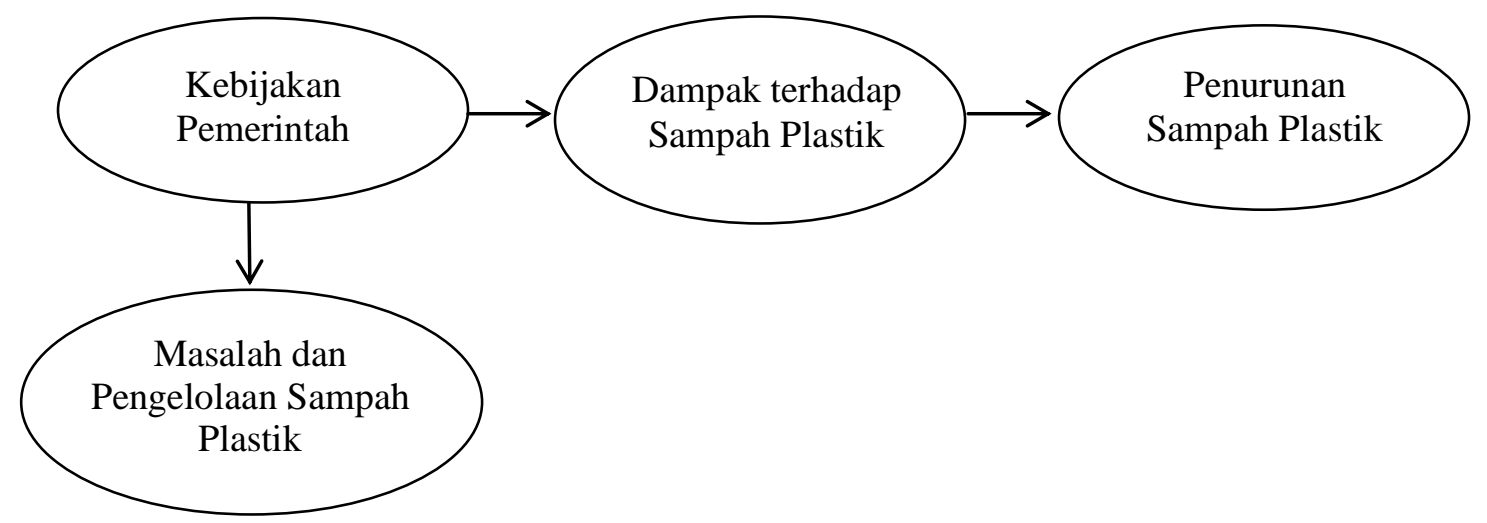

Gambar 1. Kerangka Pemikiran

Sumber: Diolah penulis, 2020.

\section{METODE PENELITIAN}

Populasi penelitian ini adalah pembeli atau konsumen di pasar retail modern di Kota Jayapura. Selanjutnya, sampel mencakup 230 responden yang dipilih menggunakan teknik accidental sampling (Sugiyono, 2019).

Penelitian ini menggunakan baik data primer maupun data sekunder (Hardani et al., 2020). Data primer dikumpulkan menggunakan instrumen kuesioner dimana para responden diminta memberikan respon persepsi atas pertanyaan yang diajukan peneliti mengenai kebijakan pemerintah tentang sampah plastik di Kota Jayapura dan dampak penerapan kebijakan tersebut terhadap upaya mengatasi masalah sampah plastik di Kota Jayapura. Teknik wawancara dilakukan untuk memperoleh data primer pendukung yang diharapkan mempertegas persepsi para responden tersebut terhadap fenomena yang dianalisis. Teknik observasi juga digunakan untuk melengkapi data primer dengan melihat dan mencermati secara langsung perkembangan kebijakan dari pemerintah terhadap masalah sampah plastik dari tahun ke tahun yang diteliti. Berikutnya, data sekunder diperoleh melalui upaya menelaah dokumen dan laporan yang berhubungan dengan kebijakan Pemerintah Kota Jayapura terhadap masalah dan pengelolaan sampah plastik.

Data yang diperoleh selanjutnya dianalisis menggunakan metode kualitatif deskriptif yang ditujukan untuk memberikan deskripsi analisis tetapi bukan digunakan dalam membuat kesimpulan yang lebih luas (Sugiyono, 2019). Data primer utama yang diperoleh melalui instrumen kuesioner pada para responden yang terdiri dari Ibu rumah tangga, pedagang atau wirausaha, PNS dan mahasiswa, akan dihitung nilai rata-rata untuk memperoleh gambaran persepsi mereka atas 
permasalahan yang dibahas. Nilai rata-rata tersebut disajikan dalam bentuk grafik dan tabel, lalu dianalisis secara naratif.

\section{HASIL ANALISIS}

\section{Kebijakan Pemerintah mengatasi masalah Sampah Plastik di Kota Jayapura}

Perkembangan sampah di Kota Jayapura meningkat dari tahun ke tahun menimbulkan masalah yang harus diselesaikan melalui peranan aktif pemerintah dan masyarakat. Perkembangan sampah perhari di Kota Jayapura ditunjukkan dalam Tabel 1 . Berdasarkan tabel ini terlihat bahwa perkembangan sampah perhari dari tahun 2017 sampai 2018 mengalami peningkatan sebesar 3,0 persen; sementara untuk periode tahun 2018 sampai 2019 terjadi peningkatan menjadi 4,0 persen; dan di tahun 2020 pada masa pandemi meningkat dari tahun 2019 menjadi 10 persen.

Berikutnya, hasil analisis lapangan yang dilakukan peneliti mengidentifikasi adanya sejumlah kebijakan yang telah dilakukan Pemerintah Kota Jayapura dalam upaya mengatasi masalah sampah plastik. Upaya-upaya itu berupa sejumlah aturan yang dikeluarkan sebagai berikut.

Kebijakan pertama adalah upaya merespon terbitnya Surat Edaran Kementerian Lingkungan Hidup dan Kehutanan Direktorat Jenderal Pengelolaan Sampah, Limbah dan Bahan Berbahaya dan Beracun No. S1230/PSLB3-PS/2016 tanggal 17 Februari 2016 tentang kebijakan penerapan plastik berbayar. Tindak lanjut yang dilakukan oleh Pemerintah Kota Jayapura adalah munculnya keputusan mengenai uji coba kebijakan plastik berbayar yang hanya diterapkan di pasar ritel modern. Biaya yang diterapkan adalah Rp. 200,- per kantong. Uji coba kebijakan plastik berbayar ini diterapkan sampai pada bulan Juni 2016.

Pemerintah Kota Jayapura juga melakukan sejumlah sosialisasi penerapan kebijakan kantong plastik melalui sejumlah leaflet yang disebarkan kepada SKPD (saat Musrenbag Distrik), di lingkungan sekolah, pada saat kegiatan kerja bakti, pada waktu memberikan pelayanan melalui Dinas Kependudukan dan Catatan Sipil, Bapenda dan juga saat pelayanan di kantor-kantor yang langsung memberikan pelayanan kepada masyarakat.

Peraturan Pemerintah pada tahun 2018 yaitu Peraturan Walikota Jayapura Nomor 19 tahun 2018 tentang Kebijakan dan Strategi Daerah Kota Jayapura diterbitkan dalam upaya pengelolaan sampah rumah tangga dan sampah sejenis sampah rumah tangga dengan target pengurangan dan penanganan sampah rumah tangga dan sampah sejenis sampah rumah tangga di wilayah Kota Jayapura.

Pemerintah Kota Jayapura selanjutnya mengeluarkan Instruksi Walikota Jayapura Nomor 1 Tahun 2019 tentang penerapan penggunaan kantong belanja alternatif pengganti kantong plastik di Kota Jayapura. Peraturan atau instruksi ini diterapkan pada lingkup pasar modern (mall, toko retail, swalayan ataupun pusat pembelanjaan) yang ada di wilayah Kota Jayapura. Penerapan instruksi ini berlaku sejak tanggal 01 Februari 2019. Sejak diberlakukan aturan ini maka pasar modern tidak lagi menyediakan kantong plastik ketika pembeli membeli barangbarang di toko-toko di Kota Jayapura, sehingga pembeli akan membawa sendiri kantong alternatif pengganti kantong plastik ataupun membeli kantong alternatif yang dijual di toko-toko tersebut. 
Tabel 1. Perkembangan Sampah per Hari di Kota Jayapura (Periode 2017-2020)

\begin{tabular}{ccc}
\hline Tahun & Volume Sampah per Hari (ton) & Perubahan $(\%)$ \\
\hline 2017 & 292 & - \\
2018 & 302 & 3,0 \\
2019 & 313 & 4,0 \\
2020 & 344,3 & 10,0 \\
\hline
\end{tabular}

Sumber: Data primer diolah, 2020.

Tabel 2. Kebijakan Pemerintah Kota Jayapura tentang Sampah Plastik (Periode 2016-2029)

\begin{tabular}{|c|c|c|}
\hline Tahun & Dasar Kebijakan & Materi Kebijakan \\
\hline 2016 & $\begin{array}{l}\text { Surat Edaran No. SE-06/PSLB3- } \\
\text { PS/2016 }\end{array}$ & $\begin{array}{l}\text { Pengurangan sampah plastik melalui } \\
\text { penerapan kantong belanja plastik sekali } \\
\text { pakai tidak gratis }\end{array}$ \\
\hline 2017 & Surat Edaran N0.660.1/886/2016 & Pengurangan penggunaan kantong plastik \\
\hline 2018 & $\begin{array}{l}\text { Peraturan Walikota Jayapura Nomor } 19 \\
\text { Tahun } 2018\end{array}$ & $\begin{array}{l}\text { Kebijakan dan strategi daerah Kota } \\
\text { Jayapura dalam pengelolaan sampah rumah } \\
\text { tangga dan sampah sejenis sampah rumah } \\
\text { tangga }\end{array}$ \\
\hline 2019 & $\begin{array}{l}\text { Instruksi Walikota Jayapura Nomor } 1 \\
\text { Tahun } 2019\end{array}$ & $\begin{array}{l}\text { Penerapan penggunaan kantong belanja } \\
\text { alternatif pengganti kantong plastik di Kota } \\
\text { Jayapura }\end{array}$ \\
\hline
\end{tabular}

Sumber: Tanan \& Duri, 2021.

Dalam mendukung penurunan sampah plastik di Kota Jayapura, terdapat juga dalam program Adipura, demikian juga adanya program Adiwiyata pada sekolah-sekolah di Kota Jayapura. Berkaitan dengan program pengolahan sampah plastik organik dan non organic, ada juga kebijakan daur ulang botol plastik dimana Pemerintah Kota Jayapura menyelenggarakan lomba membuat Pohon Natal dari botol plastik.

Demikian juga program Bank Sampah yang melibatkan kelompok masyarakat dalam tingkat RT/RW dengan mengumpulkan plastik, kertas dan almunium yang kemudian akan di jual kepada pengepul yang berlokasi di Abe dan Sentani; program "Kampung Iklim" untuk pengolahan sampah organik dan non organic; kebijakan pengolahan sampah plastik yang ditetapkan yaitu pemerintah sebesar 70 persen dan 30 persen dari masyarakat; serta, program membagikan kantong belanja gratis dan botol minum gratis di pusat perbelanjaan. Pada kantor Walikota Kota Jayapura sudah diterapkannya larangan penyajian minuman dalam kemasan botol plastik.

Untuk mengetahui efektivitas penerapan aturan ini, langkah selanjutnya adalah dengan menganalisis dampak dari kebijakan pemerintah terhadap penurunan volume sampah plastik di Kota Jayapura. Instruksi dari Walikota tentang larangan penggunaan kantong plastik, bagaimanapun, telah diterapkan di mall, supermarket ataupun ritel modern. Akan tetapi, instruksi ini belum diterapkan untuk lingkup pasar tradisional (Tanan \& Duri, 2021). Rangkaian kebijakan pemerintah ini dapat ditunjukkan dalam Tabel 2 yang mengemukakan kebijakan pemerintah yang sudah diberlakukan atau diterapkan dalam mengatasi masalah dan pengelolaan sampah plastik. 


\section{Dampak Penerapan Kebijakan Pemerintah dalam mengatasi Masalah dan Pengelolaan Sampah Plastik di Kota Jayapura}

Untuk mengetahui dampak dari pelaksanaan kebijakan plastik berbayar yang diterapkan maka Pemerintah Kota Jayapura menyebar poling kepada 1.000 orang anggota masyarakat. Hasil poling tersebut menyatakan bahwa 75,2 persen dari para responden tersebut menginginkan adanya penerapan harga plastik berbayar sebesar Rp. 200,sampai Rp. 500,- per kantong; 12,7 persen menginginkan penerapan harga plastik berbayar sebesar Rp. 500,- sampai Rp. 600,per kantong; 6,5 persen menginginkan penerapan harga plastik berbayar sebesar Rp. 750,- sampai Rp. 1.000,- per kantong; dan, 5,6 persen menginginkan penerapan harga plastik berbayar lebih besar dari Rp. 1.000.per kantong.

Selain itu, juga dilakukan monitoring oleh pihak Kementerian Lingkungan Hidup terhadap penerapan kebijakan plastik berbayar di Kota Jayapura pada bulan Mei tahun 2016. Hasil monitoring penerapan kebijakan plastik berbayar di lingkup ritel modern ini dilakukan pada sejumlah toko, seperti Supermarket Saga Jayapura, Hypermart Jayapura, Supermarket Saga Abepura, Mega Abepura, Surya Jayapura, Gelael, Hypermart Abepura, Robinson Supermarket, Toko Aneka, dan sejumlah toko lainnya. Proses monitoring ini dijalankan selama masa penerapan program plastik berbayar selama 3 bulan.

Melalui proses monitoring tersebut terobservasi bahwa pelaksanaan kebijakan plastik berbayar ini mengalami sejumlah kendala, seperti kurangnya kesadaran masyarat dalam mengurangi sampah plastik, adanya konsumen yang belum bersedia membayar Rp. 200,- untuk penggunaan plastik yang terbuat dari bahan oxium, ataupun fakta bahwa tidak semua retail menggunakan plastik biodegradable.

Untuk mengatasi kendala-kendala itu, Pemerintah Kota Jayapura terus melakukan sosialisasi pengurangan penggunaan kantong plastik untuk mengurangi dampak sampah plastik di Kota Jayapura. Demikian juga kegiatan daur ulang sampah plastik di masyarakat baik berupa pelatihan-pelatihan untuk dapat mengurangi sampah plastik di lingkungan masyarakat.

Implementasi terkait Instruksi Walikota Jayapura Nomor 1 Tahun 2019 tentang penerapan penggunaan kantong belanja alternatif pengganti kantong plastik di Kota Jayapura efektif dilakukan mulai tanggal 01 Februari 2019. Penerapan instruksi ini berdampak pada penurunan penggunaan kantong plastik belanja khususnya di pasar modern, sehingga meningkatkan kesadaran masyarakat untuk tidak lagi menggunakan kantong plastik dan menjadi kebiasaan masyarakat untuk menyediakan kantong belanja alternatif pada saat berbelanja. Lebih jauh, apabila dilihat dari dampak instruksi Walikota Jayapura terhadap sampah plastik maka penurunan sampah plastik dinilai sudah mengalami penurunan walaupun belum sepenuhnya signifikan. Hal ini karena kondisi penerapan peraturan yang dibuat pemerintah tersebut belum diterapkan di pasar tradisional.

Hasil analisis terhadap dampak dari kebijakan-kebijakan yang dijalankan pihak pemerintah dalam mengatasi masalah dan pengelolaan sampah plastik di Kota Jayapura dapat dilihat melalui persepsi para anggota masyarakat. Dalam penelitian ini digunakan 230 responden yang merupakan pembeli atau konsumen di sejumlah pasar modern yang tersebar di Kota Jayapura. Hasil penyebaran kuesioner atas para responden itu ditunjukkan dalam Tabel 3. 
Tabel 3. Persepsi Masyarakat terhadap Dampak Kebijakan Pemerintah terhadap masalah Sampah Plastik di Kota Jayapura

\begin{tabular}{lcc}
\hline \multicolumn{1}{c}{ Persepsi Masyarakat } & Jumlah (Orang) & Jumlah (\%) \\
\hline Menurunkan sampah plastik & 74 & 32,0 \\
Belum sepenuhnya menurunkan sampah plastik & 98 & 43,0 \\
Tidak menurunkan sampah plastik & 58 & 25,0 \\
\hline \multicolumn{1}{c}{ Total Jumlah } & 230 & 100,0 \\
\hline
\end{tabular}

Sumber: Tanan \& Duri, 2021.

Berdasarkan Tabel 3 diidentifikasi bahwa mayoritas anggota masyarakat (98 orang atau $43 \%$ ) menilai bahwa berbagai kebijakan yang telah diupayakan Pemerintah Kota Jayapura belumlah mampu sepenuhnya menurunkan persoalan sampah plastik. Sebanyak 58 orang $(25 \%)$ dari total responden menyatakan bahwa berbagai kebijakan Pemerintah Kota Jayapura tersebut tidak mampu menurunkan persoalan sampah plastik. Sementara 74 orang (32\%) lainnya dari total responden berpendapat bahwa berbagai kebijakan Pemerintah Kota Jayapura yang telah dilakukan selama ini sudah mampu menurunkan persoalan sampah plastik di wilayah Kota Jayapura.

Berdasarkan sejumlah fakta di lapangan ini, seperti yang ditemui oleh Olusunmade (2019) dalam penelitiannya, meskipun hampir 50 persen dari populasi yang diteliti untuk penelitian tersebut mengaku sadar akan bahaya limbah plastik, akan tetapi masih terdapat perilaku ketidakpedulian dalam cara penanganan limbah plastik ini. Situasi ini dapat diamati dari cara pembuangan limbah secara sembarangan, sehingga menciptakan tumpukan sampah di sekitar lingkungan (Muslihun et al., 2020). Konsumen masih terkesan cuek mengingat sampah kantong plastik sebagai prioritas sampah yang mendesak, sehingga kondisi ini membuat kebijakan pemerintah menjadi masih kurang efektif dalam mengubah perilaku konsumen.

\section{Pembahasan}

Berdasarkan hasil-hasil penelitian yang diperoleh maka diidentifikasi terdapat sejumlah kebijakan pemerintah terhadap masalah dan pengolahan sampah plastik yang telah diterapkan di Kota Jayapura. Hasil-hasil ini juga didukung dengan hasil penelitian sebelumnya milik Tanan \& Duri (2021) yang menelaah tentang surat edaran Menteri Lingkungan Hidup, surat edaran, sosialisasi, Peraturan Walikota dan Instruksi Walikota.

Berdasarkan hasil telaah persepsi masyarakat diperoleh kebanyakan mereka menjawab bahwa kebijakan-kebijakan milik pemerintah belum secara keseluruhan mampu menurunkan persoalan sampah plastik. Dengan kata lain, adanya sejumlah kebijakan Pemerintah Kota Jayapura dapat menurunkan masalah sampah plastik, tetapi belum maksimal atau belum sepenuhnya efektif. Pendapat para responden ini didukung alasan bahwa masih banyak ditemukan botol-botol plastik di saluran-saluran pembuangan air, apalagi pada saat musim hujan. Jawaban responden yang lain mengemukakan bahwa kebijakan pemerintah mampu menurunkan sampah plastik karena terjadi penurunan penggunaan kantong belanja dan bahkan tidak lagi tersedianya kantong plastik di pusat perbelanjaan pada saat masyarat berbelanja.

Jawaban responden selanjutnya mengemukakan bahwa kebijakan pemerintah tidak dapat mengatasi persoalan sampah plastik dengan alasan masih ditemukan sampah 
plastik serta masih banyak masyarakat yang tidak membuang sampah pada tempatnya. Jawaban terakhir ini senada dengan hasil penelitian milik Muslihun et al. (2020) yang mengidentifikasi bahwa kebijakan yang diberlakukan masih kurang efektif untuk memperbaiki kebiasaan konsumen.

Berdasarkan hasil persepsi masyarakat tersebut bila dikaitkan dengan volume sampah plastik di wilayah Kota Jayapura maka bukan saja dibutuhkan peran kebijakan pemerintah, tetapi juga kesadaran aktif dari masyarakat untuk bersedia membuang sampah pada tempatnya dan juga dapat mengelolanya menjadi sampah bernilai ekonomis. Menurut Andrawina et al. (2019), masyarakat seharusnya berperan aktif menjadi pengambil inisiatif dikarenakan mereka adalah penghasil utama sampah plastik. Sehingga berdasarkan hasil kuisioner itu dinyatakan bahwa masyarakat lebih dominan dengan jawaban bahwa adanya kebijakan Pemerintah Kota Jayapura terhadap masalah sampah plastik di Kota Jayapura adalah sudah mampu menurunkan volume sampah plastik tetapi belum sepenuhnya mengatasi permasalahan tersebut.

Kondisi ini dinilai terutama karena instruksi dari Walikota berkenaan dengan larangan penggunaan kantong plastik di Pasar modern masih belum sepenuhnya mengatasi masalah sampah plastik di Kota Jayapura. Untuk itu diperlukan tindak lanjut terhadap dampak kebijakan yang telah diterapkan, misalnya dengan merujuk saran Khan et al. (2019) agar pihak pemerintah pusat maupun daerah berupaya meningkatkan program daur ulang sampah baik yang dikelola oleh pemerintah ataupun oleh masyarakat sebagai upaya mengatasi persoalan sampah plastik

\section{SIMPULAN}

Kebijakan Pemerintah Kota Jayapura dalam mengatasi masalah sampah plastik mengacu pada beberapa kebijakan sampai dengan penerbitan Instruksi Walikota tentang penerapan penggunaan kantong belanja alternatif pengganti kantong plastik di Kota Jayapura. Dampak dari penerapan kebijakan pemerintah tersebut berdasarkan hasil kuesioner diperoleh mayoritas masyarakat berpendapat bahwa masih belum sepenuhnya mengatasi permasalahan sampah plastik di Kota Jayapura.

Hasil yang diperoleh ini diharapkan menjadi masukan bagi Pemerintah dalam mengambil langkah kebijakan selanjutnya dalam penanganan sampah plastik, terutama dalam memunculkan upaya-upaya yang dapat mendorong peningkatan partisipasi dari masyarakat sehingga lebih berperan dalam mengatasi persoalan sampah plastik. Selain itu, diharapkan pemerintah daerah juga berusaha meningkatkan kualitas dan kuantitas dari fasilitas pendukung terkait pengolahan sampah plastik tersebut.

Hasil penelitian ini diekspektasikan menjadi bahan evaluasi bagi Pemerintah Kota Jayapura terhadap kebijakan-kebijakan yang dimunculkannya serta dampaknya dalam mengurangi sampah plastik di masyarakat, apalagi dalam masa pandemi Covid-19 saat ini. Bagaimanapun, dampak terkait kebijakan yang dianalisis dalam penelitian ini dinilai masih memiliki kelemahan karena masih sebatas persepsi masyarakat saja, sehingga direkomendasikan agar bahasan topik ini dibahas lebih mendalam ataupun lebih komprehensif oleh para peneliti berikutnya.

\section{UCAPAN TERIMA KASIH}

Terimakasih kepada Kementerian Riset dan Teknologi/Badan Riset dan Inovasi Nasional Deputi Bidang Penguatan Riset dan Pengembangan, Kepala Dinas Lingkungan Hidup dan Kebersihan Kota Jayapura dan LP2M Universitas Ottow Geissler Jayapura yang telah membantu sehingga penelitian ini dapat dilaksanakan. 


\section{REFERENSI}

Andrawina, K. E., Zulfikri, A., Maranatha, T. R. R., \& Handayani, W. (2019). Women and wastes: Study on participation of housewives on plastic waste management in Kecandran, Salatiga, Indonesia. Sustinere, Journal of Environment \& Sustainability, 3(3), 127-212. doi: 10.22515/sustinere.jes. v3i3.90.

Astuti, A. D. (2018). Penerapan kantong plastik berbayar sebagai upaya mereduksi penggunaan kantong plastik. Jurnal Litbang: Media Informasi Penelitian, Pengembangan dan IPTEK, 12(1), 32-40. doi: 10.33658/j1.v12i1.50.

Bai, M., Zhu, L., An, L., Peng, G., \& Li, D. (2018). Estimation and prediction of plastic waste annual input into the sea from China. Acta Oceanologica Sinica, 37(11), 26-39. doi: 10.1007/s13131018-1279-0.

Brooks, A. L., Wang, S., \& Jambeck, J. R. (2018). The Chinese import ban and its impact on global plastic waste trade. Science Advances, 4(6), 1-8. doi: 10.1126/sciadv.aat0131.

Ciuffi, B., Chiaramonti, D., Rizzo, A. M., Frediani, M., \& Rosi, L. (2020). A critical review of SCWG in the context of available gasification technologies for plastic waste. Applied Sciences (Switzerland), 10(18), 1-35. doi: 10.3390/APP10186307.

Fangga \& Mulasari, S. A. (2016). Kebijakan pemerintah dalam pengelolaan sampah domestik di Kabupaten Bantul Propinsi D.I. Yogyakarta. Jurnal Kesehatan Masyarakat, 9(2), 1-14. Retrieved from: http://eprints.uad.ac.id/8013/.

Gultom, E. N. (2020). Analisis ekstensifikasi barang kena cukai terhadap kantong plastik di Indonesia. Jurnal Perspektif Bea dan Cukai, 4(2), 166-178. doi: 10.31092/jpbc.v4i2.965.

Hardani, Auliya, N. H., Andriani, H., Fardani, R. A., Ustiawaty, J., Utami, E. F., Sukmana, D. J., \& Istiqomah, R. R. (2020). Metode penelitian kualitatif \& kuantitatif. CV. Pustaka Ilmu.

Instruksi Walikota Jayapura Nomor 1 Tahun 2019 tentang Penerapan Penggunaan Kantong Belanja Alternatif Pengganti Kantong Plastik di Kota Jayapura. Jayapura.

Khan, F., Ahmed, W., \& Najmi, A. (2019). Understanding consumers' behavior intentions towards dealing with the plastic waste: Perspective of a developing country. Resources, Conservation and Recycling, 142(September), 49-58. doi: 10.1016/j.resconrec.2018.11.020.

Klemeš, J. J., Fan, Y. V., Tan, R. R., \& Jiang, P. (2020). Minimising the present and future plastic waste, energy and environmental footprints related to COVID-19. Renewable and Sustainable Energy Reviews, 127(109883), 1-7. doi: 10.1016/j.rser.2020.109883.

Mahyudin, R. P. (2017). Kajian permasalahan pengelolaan sampah dan dampak. Jukung Jurnal Teknik Lingkungan, 3(1), 66-74. doi: 10.20527/jukung. v3i1.3201.

Mangkoesoebroto, G. (2016). Ekonomi publik. BPFE.

Maolani, D. Y., \& Ishak, D. (2018). Implementasi kebijakan pemerintah dalam pengelolaan sampah di Kabupaten Dili Negara Timor Leste. Jurnal Kelola: Jurnal Ilmu Sosial, 1(2), 117-130. doi: 10.15575/jk.v1i2.3780.

Mirnawati. (2018). Analisis kinerja pengolahan sampah di Kota Metro (Studi di tempat pengolahan akhir sampah (TPAS) Kota Metro. Administratio: Jurnal Ilmiah Administrasi Publik dan Pembangunan, 9(2), 108-116. Retrieved from: https://www.google.com/url?sa=t\&rct=j $\& \mathrm{q}=\&$ esrc $=$ s $\&$ source $=$ web $\& c d=\& c a d=$ rja\&uact $=8 \&$ ved $=2$ ahUKEwjU7b3wMPwAhXRbn0KHSq5DQIQFjACe gQICRAD\&url=http $\% 3 \mathrm{~A} \% 2 \mathrm{~F} \% 2 \mathrm{Fjurn}$ aladministratio.fisip.unila.ac.id\%2Finde x.php $\% 2$ Fadministratio $\% 2$ Farticle $\% 2 \mathrm{~F}$ download $\% 2 \mathrm{~F} 70 \% 2 \mathrm{~F} 51 \% 2 \mathrm{~F} \&$ usg $=\mathrm{AO}$ vVaw2TD1saE-VZiurdEnvpxb8E. 
Mulasari, S. A., Husodo, A. H., \& Muhadjir, N. (2014). Kebijakan pemerintah dalam pengelolaan sampah domestik. Kesmas: National Public Health Journal, 8(8), 404-410. doi: 10.21109/kesmas.v8i8. 412.

Muryono, S. (2018). Pertemuan menteri lingkungan hidup menghasilkan Deklarasi Bali. Antaranews.com. Edisi hari Jumat, tanggal 02 November 2018. Retrieved from https://www.antara news.com/berita/764568/pertemuanmenteri-lingkungan-hidupmenghasilkan-deklarasi-bali.

Muslihun, M., Anggroro, D. D., \& Kismartini, K. (2020). An environmental study on the paid plastic bag use policy in the city of Semarang. The $5^{\text {th }}$ International Conference on Energy, Environmental and Information System (ICENIS 2020), E3S Web of Conferences, 202. doi: 10.1051/ e3sconf/202020206001.

Novianti, A. I., \& Kartika, L. (2017). Pengaruh green marketing kebijakan kantong plastik berbayar terhadap green behaviour masyarakat Kota Bogor. Jurnal Riset Manajemen dan Bisnis, 2(1), 81-94. doi: 10.36226/jrmb. v2i1.32.

Olusunmade, O. F. (2019). Plastic wastes separation practice and disposal mechanism by households, hospitals, markets and waste management body. International Journal of Human Capital in Urban Management, 4(3), 189-204. doi: 10.22034/IJHCUM.2019. 03.04.

Palugaswewa, I. J. K. (2018). Sustainable plastic waste management in Sri Lanka: Effective policy approaches. IIIEE Master Thesis. The International Institute for Industrial Environmental Economics, Sweden. Retrieved from https://lup.lub.lu.se/studentpapers/search/publication/8962482.

Peraturan Walikota Jayapura Nomor 19 Tahun 2018 tentang Kebijakan Dan Strategi Daerah Kota Jayapura dalam Pengelolaan Sampah Rumah Tangga dan Sampah sejenis Sampah Rumah Tangga. Jayapura.

Prasetyia, F. (2012). Bagian V: Teori eksternalitas. Jurusan Ilmu Ekonomi Fakultas Ekonomi dan Bisnis Universitas Brawijaya. Retrieved from https://www.google.com/url?sa=t\&rct=j $\& \mathrm{q}=\&$ esrc $=$ s $\&$ source $=$ web $\& \mathrm{~cd}=\& \mathrm{cad}=$ rja\&uact $=8 \&$ ved $=2$ ahUKEwiMtPaq5sL wAhUaqksFHczBDgIQFjAAegQIAxA D\&url=http $\% 3 \mathrm{~A} \% 2 \mathrm{~F} \% 2 \mathrm{Fferryfebub} . \mathrm{le}$ cture.ub.ac.id\%2Ffiles\%2F2013\%2F01 \%2FBagian-V-Teori-Eksternalitas.pdf \&usg=AOvVaw1DdcJyZjsFGwceekT8 K9GT.

Prisandani, U. Y., \& Amanda, A. L. (2019). The importance of regulating plastic marine pollution for the protection of Indonesian marine environment. Yuridika, 35(1), 171-185. doi: 10.20473/ydk.v35i1.10962.

Purwoko, P., \& Wibowo, T. (2018). Fiscal incentives and disincentives to reduce plastic waste. Proceeding, 213-218. The 6th Asian Academic Society International Conference (AASIC) " $A$ Transformative Community: Asia in Dynamism, Innovation, and Globalization". Retrieved from: https:// www.google.com/url?sa=t\&rct=j\&q=\& esrc $=$ s\& source $=$ web $\& c d=\& c a d=r j a \& u a$ $\mathrm{ct}=8 \& \mathrm{ved}=2 \mathrm{ahUKEwjZzczDwsPwAhX}$ 79nMBHSUsBmgQFjAAegQIAxAD\& url=http $\% 3 \mathrm{~A} \% 2 \mathrm{~F} \% 2 \mathrm{Faasic}$. org $\% 2 \mathrm{Fpro}$ c\%2Faasic\%2Farticle $\% 2$ Fdownload $\% 2$ $\mathrm{F} 360 \% 2 \mathrm{~F} 357 \&$ usg=AOvVaw3AUbEP RKqooDLASw6EKoro.

Putri, N. W. E. (2019). Komunikasi sosial dalam mensosialisasikan penetapan kebijakan Gubernur Bali tentang pembatasan timbulan sampah plastik sekali pakai. Jurnal Nomosleca, 5(1), 44-57. doi: 10.26905/nomosleca.v5i1. 2783.

Ramah. (2017). Butuh komitmen bersama masalah sampah di Kota Jayapura. Kabarpapua.Co. Edisi 16 Juli 2017. Retrieved from https://kabarpapua.co/ butuh-komitmen-bersama-masalahsampah-di-kota-jayapura/. 
Saputri, M. M. (2015). Evaluasi dampak kebijakan pemerintah daerah dalam pengelolaan sampah melalui program bank sampah (Studi di Bank Sampah Sumber Rejeki Kelurahan Bandar Lor Kecamatan Mojoroto Kota Kediri). Jurnal Administrasi Pubik, 3(11), 1804-1808. Retrieved from: http:// administrasipublik.studentjournal.ub.ac. id/index.php/jap/article/view/1048.

Saraswaty, A. N. (2018). Kebijakan publik dan ritel modern: Studi kasus pelaksanaan kebijakan plastik berbayar. E-Jurnal Ekonomi dan Bisnis Universitas Udayana, 7(1), 113-142. doi: 10.24843/EEB.2018.v07.i01.p05.

Septiadi, A. (2018). Pemerintah tetapkan kebijakan pengelolaan sampah nasional. Kontan.co.id. Edisi hari Selasa, tanggal 16 Januari 2018. Retrieved from https://nasional.kontan. co.id/news/pemerintah-tetapkankebijakan-pengelolaan-sampahnasional.

Siahaan, N. H. T. (2004). Hukum lingkungan dan ekologi pembangunan. Erlangga.

Sugiyono. (2019). Metode penelitian kuantitatif, kualitatif, dan $R \& D$. Alfabeta.

Surat Edaran Kementerian Lingkungan Hidup dan Kehutanan Direktorat Jenderal Pengelolaan Sampah, Limbah dan Bahan Berbahaya dan Beracun No. S1230/PSLB3-PS/2016 Tanggal 17 Februari 2016 tentang kebijakan penerapan plastik berbayar. Jakarta.

Tanan, C. I., \& Duri, J. A. (2021). Kebijakan pemerintah dalam mengatasi eksternalitas dan pengelolaan sampah plastik di Kota Jayapura. JIMEA: Jurnal Ilmiah MEA (Manajemen, Ekonomi, dan Akuntansi), 5(1), 1-16. Retrieved from http://journal.stiemb.ac. id/index.php/mea/article/view/656/337.

Wanda. (2019). Upaya Indonesia menanggulangi limbah sampah plastik dari Belanda. JOM FISIP, 6(1), 1-12.
Retrieved from: https://jom.unri.ac.id/ index.php/JOMFSIP/article/view/23406

Wang, Z., Huo, J., \& Duan, Y. (2020). The impact of government incentives and penalties on willingness to recycle plastic waste: An evolutionary game theory perspective. Frontiers of Environmental Science \& Engineering, 14(2), 29. doi: 10.1007/s11783-0191208-2.

Wichai-utcha, N., \& Chavalparit, O. (2019). 3Rs policy and plastic waste management in Thailand. Journal of Material Cycles and Waste Management, 21, 10-22. doi: 10.1007/s10163-018-0781-y.

Widiantara, I. K. A. (2020). Strategi public relations Pemprov Bali menuju Bali bebas sampah plastik. Ganaya: Jurnal Ilmu Sosial dan Humaniora, 2(2-3), 84-91. Retrieved from: https://jaya panguspress.penerbit.org/index.php/gan aya/article/view/390.

Willis, K., Maureaud, C., Wilcox, C., \& Hardesty, B. D. (2018). How successful are waste abatement campaigns and government policies at reducing plastic waste into the marine environment? Marine Policy, 96(October), 243-249. doi: 10.1016/j.marpol.2017.11.037.

Yuliyah. (2018). Indonesia darurat sampah plastik. Tanganrakyat.id. Edisi Selasa, tanggal 27 November 2018. Retrieved from https://www.tanganrakyat.id/ 2018/11/27/indonesia-darurat-sampahplastik/.

Yustikarini, R., Setyono, P., \& Wiryanto, W. (2017). Evaluasi dan kajian penanganan sampah dalam mengurangi beban tempat pemrosesan akhir sampah di TPA Milangasri Kabupaten Magetan. Proceeding Biology Education Conference, 14(1), 177-185. Retrieved from https://jurnal.uns.ac.id/prosbi/ article/view/17642. 